\title{
Examining the Educational Sections of Development Plans in Turkey in the Context of Educational Administration
}

\section{Türkiye'deki Kalkınma Planlarının Eğitim Bölümlerinin Eğitim Yönetimi Bağlamında İncelenmesi}

\begin{abstract}
Abdullah BALIKÇI*
Received: 02 June 2020

Research Article

Accepted: 16 November 2020

ABSTRACT: Development-education interaction can be seen clearly in development plans. This study aims at making inferences about educational administration from the educational sections of the development plans in Turkey since 1963. This study was carried out with a qualitative research method. The data were analyzed using descriptive analysis approach. In this study, 11 development plans prepared since 1963 in Turkey were analyzed in terms of educational administration. Special expert commission reports prepared for development plans are included in the analysis. It was seen that the following points come to the fore in the context of educational administration: MoNEbased organization should be reviewed. The administrative processes should be implemented more effectively. Educational administration-environment interaction should increasingly be maintained. Arrangements should be made for the development and duties of educational administrators. For researchers, it can be recommended to conduct studies with different methods and studies on the problems between planning and implementation related to educational administration. For practitioners, it can be recommended to include educational administration experts in the planning process more and effectively, and include them in education plans more.
\end{abstract}

Keywords: Development plan, educational planning, educational administration.

ÖZ: Kalkınma- eğitim etkileşimi kalkınma planlarında açıkça görülebilmektedir. Bu çalışmada amaç, 1963 yılından bu yana yapılmış kalkınma planlarındaki eğitim bölümlerinde eğitim yönetimine yönelik çıkarımlarda bulunmaktır. Çalışmada nitel araştırma yöntemi kullanılmıştır. Veriler, betimsel analiz yaklaşımıyla analiz edilmiştir. Çalışmada, 1963 yılından günümüze yapılan 11 kalkınma planı eğitim yönetimi açısından analiz edilmiştir. Analize kalkınma planlarına yönelik hazırlanmış özel ihtisas komisyonu raporları dahil edilmiştir. Araştırmada eğitim yönetimi bağlamında şu noktaların ön plana çıktığı görülmektedir: MEB merkezli teşkilatlanmanın gözden geçirilmesi ihtiyacı vardır. Yönetim süreçlerinin daha etkin uygulanması gerekmektedir. Eğitim yönetimi-çevre etkileşiminin gittikçe artan bir şekilde sürdürülmesi gerekmektedir. Eğitim yöneticilerinin gelişimine ve görevlerine yönelik düzenlemeler yapılmalıdır. Araştırmayla ilgili olarak araştırmacılar için eğitim yönetimi alanıyla ilgili tüm planları kapsayacak şekilde farklı yöntemle araştırmalar yapılması, planlama ile uygulama arasındaki problemlerin araştırma konusu yapılması önerilebilir. Uygulayıcılar için, eğitim yönetimi uzmanlarının planlama sürecinde daha fazla ve etkin bir şekilde katılması, eğitime planlarda daha fazla yer verilmesi önerilebilir.

Anahtar kelimeler: Kalkınma planı, eğitim planlaması, eğitim yönetimi.

* Corresponding Author: Asst. Prof. Dr., Istanbul University-Cerrahpaşa, Istanbul, Turkey, abdullah.balikci@istanbul.edu.tr, https://orcid.org/0000-0002-9824-0197

Citation Information

Balıkçı, A. (2021). Examining the educational sections of development plans in Turkey in the context of educational administration. Kuramsal Eğitimbilim Dergisi [Journal of Theoretical Educational Science], 14(1), 1-19. 
It is suggested that planning should include the decisions regarding the regulations to be made for the future (Koçel, 2001). Due to this relationship, countries are preparing their development plans. Development is expected in various domains of society (social, political, and economic, etc.). Social and individual gains can emerge with the realization of these expectations. These gains have a social dimension as well as the economic, environmental, and educational dimensions. Achieving and maintaining gains benefit from the concept of sustainable development today (Directorate of Strategy and Budget [DSB], 2018; Karakütük, 2019). Sustainable development can be realized through certain logic, central work, and planning that covers many social, economic, and environmental factors (Crowson, 1992; Tian, 2016). Başaran (1993) defines it as a simple, reliable, and economic study that can be continuously improved and includes planning, future-oriented activities, objectives desired to be achieved, and measurable results. Koçel (2001) suggests that planning is the decision regarding the regulations to be made for the future. For this, it is necessary to determine the goals, risks, and assumptions of the plans to be made as well as investigating and examining the things to be done in the future. The importance of planning for the organization makes it necessary for the administrators to make plans. Kondakçı and Zayim (2013) state that a plan is a decisive study for the realization of the decision and targets within organizations and its scope is what is desired and expected to be done in the future. Küçükali (2011) defines the aim in planning as creating order by preventing disorder in the organization while Balyer (2019) defines it as making decisions, designing the future, and satisfying the targeted groups and meeting their expectations. Another approach to planning is that planning can be a means with a compass and a road map in reaching the goals of planning. For a means to serve its purpose, the resources to be utilized should be determined and used effectively. Today, this means can be implemented as a strategic plan at the level of organizations (Beach \& Lindahl, 2015; Gümüş \& Şişman, 2012).

Considering the history of planning, it is seen that economic concerns have come to the fore (Ekiz \& Somel, 2007). In addition to this, planning has come to the agenda in terms of development especially after the Second World War (Kaya, 2015, p. 8). After the Second World War, many countries have tended to make development plans to solve their problems in various fields (economic, political, education, health, etc.). Organizations such as the United Nations (UN), the International Monetary Fund (IMF), the World Bank (WB), the International Labor Organization (ILO), and the Organization for Economic Cooperation and Development (OECD) have been established to help countries develop in the specified areas (Karakütük, 2019). After the proclamation of the Republic of Turkey in 1929, the solution was sought in the industrial plans due to the crisis affecting the world. As a result, the first industrial plan was prepared in 1934 (Soyak, 2003). The development plans first arrived in Turkey after the 1960s. It was stated in the 1961 Constitution, Turkey, that planning was one of the duties of the state. The State Planning Organization (SPO) was established in 1960. A Research Planning and Coordination Board (APK) was established within the Ministry of National Education to work in coordination with the SPO. With law number 5436 enacted in 2005, the board left its duty to the Strategy Development Directorate. The duties of the SPO were transferred to the Ministry of Development, which was established in 2011 (Gümüş \& Şişman, 2012, p. 149). 
One of the areas that are included in the development plans and stand out is education. The role of education in development can be seen in development plans (Kaya, 2015). Education contributes to the achievement of development goals by raising the qualified labor force in all areas, especially the economy (Karakütük, 2019). Gümüş and Şişman (2012) identify the aim of planning in education as to maximize the benefit from education and increasing the effectiveness of the education system while Yildiz and Karakütük (2017) identify it as to train qualified labor force. Günkör (2017) interprets the positive relationship between education and development as the contribution of education to the ability to train qualified people, the increase in the economic power of individuals, and the training of individuals producing technology. In addition to this, he emphasizes that it is the source of development. Akar (2010) defines the benefit of education as facilitating adaptation to constantly evolving and changing conditions while Hess, Johnson, and Reynolds (2014) define it as meeting formal and informal requirements, and, therefore, contributing in and out of the organization in both short and long term.

It is possible to benefit from education through creating a certain order between planning and education (Adem, 1979), considering the education system (Bursalıoglu, 2000), the opinions of the environment including students (Davidovitch-Marton, 2007), and various school types constituting the education system (Tian, 2016), determining the needs (Sezgin-Nartgün, 2000), preparing to reflect country's needs (Akça, Şahan, \& Tural, 2017), providing effective and efficient cooperation between sectors (Persaud, 2017), bringing together the academicians and professional organizations of the created team, and ensuring sharing and cooperation among them (Alterman, 2017). However, it is understood that there are problems in implementing the above-mentioned issues. The problem experienced here results from being unable to create a planned change in the development plans for a qualified labor force in education and to ensure desired development in terms of educational financing (Altundemir, 2012) as well as acting without a plan (Adem, 1979).

One pillar of educational planning is administration. Bayram (2019) and Crowson (1992) emphasize administration's handling the organization in all its dimensions from the top to the bottom, and having sufficient training and equipment for this while Bursalığlu (2000) suggest that the administration should make a plan with a certain order for the works to be done after making a decision. Aydin (2000) states that an administration can benefit from planning for adapting the behavior of employees to the organization. He believes that it is an effective method for the administration to coordinate by starting from the environment of the employee and to organize it in a way that reveals the potential of the employees. In this regard, Yıldız and Karakütük (2017) believe that administrators can use various statistical data (the number of students and schools, building, classrooms, etc.) when making decisions. Considering the contribution of educational planning to the administration, administrator, and, therefore, education, Küçükali (2011) addresses the issue in terms of using it as a problem-solving method. Çakmak (2008) addresses the issue in terms of contributing to the development of society and reducing problems -such as crimes- in social development. Balyer (2019) addresses the issue in terms of making things simpler and eliminating arbitrary applications. In this regard, Alexander (2001) emphasizes that administrators should be competent in his/her field while Fullan (1992) emphasizes that administrators should 
contribute to the planning of the parties related to education and organize them. Ergen (2013) suggests that administrators should emphasize their aspects of being flexible, forward-looking, and building democratically. Thus, plans can better demonstrate the performance of the administration and realistic approaches can be adopted. Similarly, Kaya (2015) states that an education plan considering both the quantity and quality dimensions will contribute to economic and social development.

There is prevailing literature on development plans, especially focusing on education planning and the contribution of development plans to education (Alterman, 2017; Argün, 2003; Aşım, 2019; Bulut, 2002; Douse \& Uys, 2018; Fullan, 1992; Gökalp, 2003; Gül, 1992; Karakütük, 2019; Korkmaz, 1995; Küçüker, 2008; Özdemir, 1997; Taş, 2007; Tuzcu, 2005; Yetkin-Ay, 2010; Yıldız \& Karakütük, 2017). However, it is considered that the educational administration dimension of development plans is not sufficiently revealed. In addition to this, unlike other studies, the current study examines all development plans. Examining all plans can contribute to understanding the issue from a holistic and chronological perspective. In this regard, it is thought that the current study will contribute to revealing the development plan-educational administration dimension. This study aims to make inferences about educational administration based on the assessments made in the context of the educational administration in development plans in Turkey since 1963.

\section{Method}

This study aims to derive meaning from the plans in the context of education. Therefore, a qualitative research method was used in this study. In a qualitative study, the aim is to explain the subject in a descriptive, realistic, deep, and detailed way to the readers so that new meanings can be inferred (Merriam, 2015a; Neuman, 2006; Patton, 2014a; Y1ldırım \& Şimşek, 2011). In this study, all development plans (from $1^{\text {st }}$ to $11^{\text {th }}$ ) available on the Presidency of the Republic of Turkey, Directorate of Strategy and Budget (DSB) website (www.sbb.gov.tr) with their full texts were used as documents to derive new meanings in the context of educational administration. In addition to these, special expertise commission reports prepared for education for the development plans were used to better analyze the evaluations made in the context of educational administration in development plans. In qualitative studies, one of the data sources can be official publications and documents based on reports (Christensen, Johnson, \& Turner, 2015; Patton, 2014a).

A descriptive analysis was used in this study. In the descriptive analysis, the aim is to ensure that readers are included in the thoughts and help them discover focal points (Patton, 2014b; Yıldırım \& Şimşek, 2011). In this study, it was attempted to perform descriptive analysis by directly quoting the assessments and items included in the development plans in the context of educational administration. In addition to this, inferences were made in terms of educational administration based on the analysis. 
Figure 1. Analysis Process of Development Plans in the Context of Educational Administration

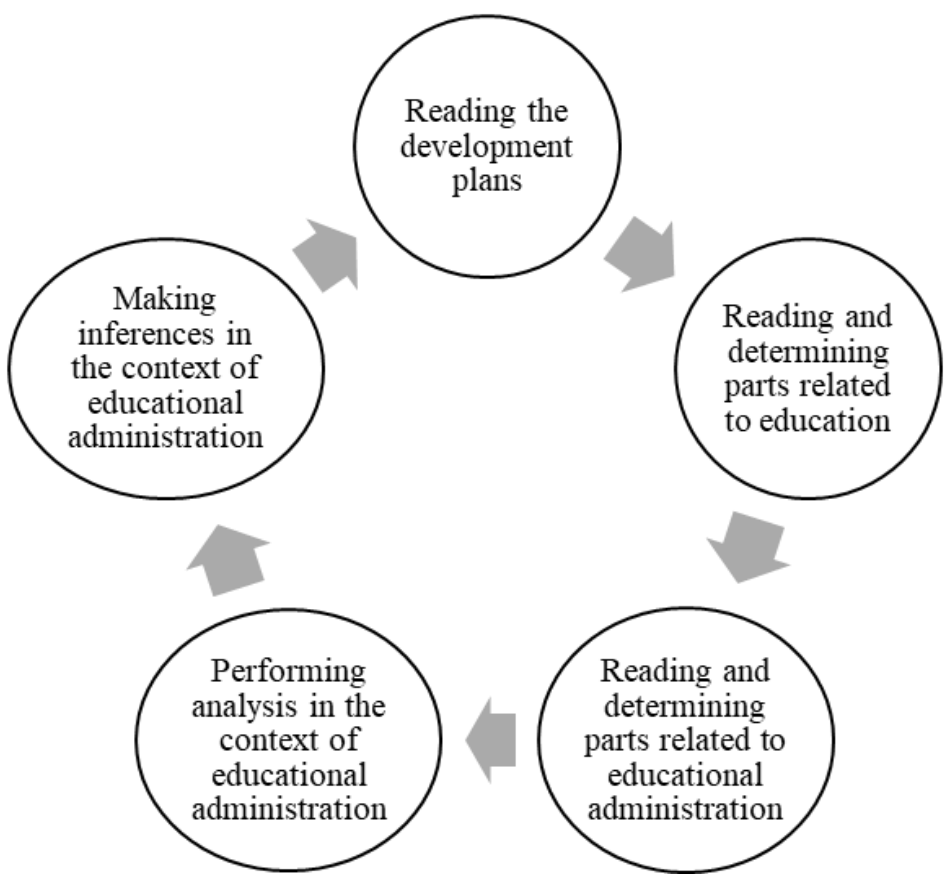

The descriptive analysis process was shown in Figure 1. The process was conducted with a deductive method and a circular approach. At the end of the process, the researcher's reflectivity, expert review, and supervision strategies were used for the reliability and validity of the emerging report (Christensen et al., 2015; Merriam, 2015b). These strategies were reflected in the study as follows: The reflectivity strategy was reflected by providing direct quotations from plans with page and item numbers and presenting Table 1 based on the analysis. Expert review strategy was reflected by taking the opinions of two academicians with different academic status and by using the assessments of Karakütük (2019). Analyses were directly related to the study and supervision strategy was reflected by considering the opinions of two academicians and one language expert. Abbreviations were used when expressing development plans. Some of the abbreviations are as follows: $1^{\text {st }}$ Five-year Development Plan as " 1 st FYDP", 9 $9^{\text {th }}$ Development Plan as "9 ${ }^{\text {th }}$ DP", Ministry of National Education, Turkey as "MoNE", Council of Higher Education as "CoHE", and Directorate of Strategy and Budget as "DSB".

\section{Findings}

In this section, all of the development plans (from $1^{\text {st }}$ to $11^{\text {th }}$ ) were analyzed in the context of educational administration. In addition to this, special expertise commission reports prepared for development plans were analyzed. However, the special expertise commission reports for the first 3 plans could not be reached. It was also seen that there were no special expertise commission reports for education in the $5^{\text {th }}, 6^{\text {th }}$ and $7^{\text {th }}$ Development Plans. The evaluations on educational administration in special expertise commission reports prepared for the remaining $4^{\text {th }}, 8^{\text {th }}, 9^{\text {th }}, 10^{\text {th }}$, and $11^{\text {th }}$ Development Plans were analyzed (www.sbb.gov.tr). It was seen that the following subjects came to the fore in the context of educational administration: Evaluations on the organizational structure of the MoNE, evaluations on administrative processes, 
evaluations on the connection between educational administration and the environment especially CoHE-, training of the educational administrators, and evaluations on their duties. The inferences for the relevant plan were presented in Table 1.

\section{Table 1}

Educational Administration in Development Plans

\begin{tabular}{|c|c|c|c|c|}
\hline $\begin{array}{l}\text { Development } \\
\text { Plan }\end{array}$ & Period & Section/Item & Page & $\begin{array}{c}\text { Situations Assessed in terms of Educational } \\
\text { Administration }\end{array}$ \\
\hline 1 & $1963-1967$ & 7 & $439-468$ & $\begin{array}{l}\text { Structural change and transformation } \\
\text { expectation in MoNE, including } \\
\text { administrative processes, cooperation with } \\
\text { the environment, training educational } \\
\text { administrators }\end{array}$ \\
\hline 2 & $1968-1972$ & 6 & $158-187$ & $\begin{array}{l}\text { Structural change and transformation } \\
\text { expectations in MoNE continue, including } \\
\text { administrative processes, cooperation with } \\
\text { the environment continues }\end{array}$ \\
\hline 3 & 1973-1977 & $4 / 12$ & $709-780$ & $\begin{array}{l}\text { Structural change and transformation } \\
\text { expectation in MoNE continue, including } \\
\text { management processes, cooperation with the } \\
\text { environment continues }\end{array}$ \\
\hline 4 & $1979-1983$ & $2 / 5$ & $433-459$ & $\begin{array}{l}\text { Structural change and transformation } \\
\text { expectations in MoNE continue, including } \\
\text { administrative processes, cooperation with } \\
\text { the environment and expectation of being } \\
\text { environment-oriented }\end{array}$ \\
\hline 5 & 1985-1989 & $4 / 6$ & $140-147$ & $\begin{array}{l}\text { Including administrative processes, training } \\
\text { educational administrators }\end{array}$ \\
\hline 6 & 1990-1994 & 4 & $291-296$ & $\begin{array}{l}\text { Including administrative processes, } \\
\text { revealing expectations from educational } \\
\text { administration and administrators }\end{array}$ \\
\hline 7 & $1996-2000$ & 3 & $23-34$ & $\begin{array}{l}\text { Including administrative processes, } \\
\text { emphasizing orientation function of MoNE, } \\
\text { attempting to realize structural change and } \\
\text { transformation in MoNE through regulation }\end{array}$ \\
\hline 8 & 2001-2005 & 8 & $80-85$ & $\begin{array}{l}\text { Including administrative processes, } \\
\text { attempting to realize structural change and } \\
\text { transformation in MoNE through regulation, } \\
\text { the need to resort to different methods, } \\
\text { indicating cooperation with the environment, } \\
\text { revealing the need for structural change in } \\
\text { CoHE }\end{array}$ \\
\hline 9 & 2007-2013 & $\begin{array}{l}570- \\
577 / 581-602 \\
(\text { article })\end{array}$ & $\begin{array}{l}84-85 \\
85-87\end{array}$ & $\begin{array}{l}\text { Including administrative processes, } \\
\text { structural change and transformation } \\
\text { expectations in MoNE continue, the need for } \\
\text { structural change in CoHE, cooperation with } \\
\text { the environment continues, school } \\
\text { administration }\end{array}$ \\
\hline
\end{tabular}


10 2014-2018

$137-165$

(article)
$31-35$

Including

administrative

processes,

assigning the coordination task to the MoNE

as well as the cooperation with the environment, including the concept of sustainable development, including the powers and responsibilities of the school administration, providing recommendations of $\mathrm{CoHE}$

Including administrative processes, arrangements for school administration and administrators, arrangements for $\mathrm{CoHE}$

Table 1 includes evaluations regarding educational administration in development plans. It was seen that there were evaluations centered on the Ministry of National Education in terms of educational administration. In addition to this, there were also evaluations regarding the interaction of administrative processes, educational administrators, and educational administration with the environment.

\section{$1^{\text {st }}$ Five-Year Development Plan (1963--1967)}

This plan consisted of 10 sections. Education was addressed in the $7^{\text {th }}$ section, from page 439 to 468 . The link between education and economy and its rationale was explained as follows: “... as it was also addressed in terms of training the necessary and sufficient number of staff to realize the work to be carried out in this period for achieving the social goals of education as well as the development goals..." (p. 441) While the reasons for not reaching the desired point in education were listed, the educational administration-centered organization problem was brought to the fore. In addition to this, being away from the holistic approach and not adapting the planned approach were among the other main problems. "...However, not considering the education system as a whole, not addressing education in a long-term framework and planned way, and disorganization in the educational institution prevented all these efforts and expenditures from being sufficiently efficient, and caused various imbalances in our education system" (p. 448). In addition to this, not training educational administrators and the lack of cooperation among institutions in this plan were also considered as problems. "It is also an important issue not to train educational administrators and not to establish necessary cooperation between Ministries and educational institutions" (p. 449).

This plan aimed at reviewing the educational organization as expressed in "the most important issue here is to bring the organization in charge of educational services to a position that can meet these services" (p. 457) creating cooperation in terms of the contribution of institutions to education as expressed in "close cooperation will be provided between institutions involving education and making plans for education" ( $\mathrm{p}$. 457), and organizing and coordinating education with the MoNE. "Various vocational schools will meet in a certain time to be carried out in cooperation with the relevant ministries and departments, the meeting will be held within the Ministry of National Education" (p. 457).

This plan evaluates education in terms of its contribution to the economy. In the context of educational administration, structural problems in the MoNE were brought 
forward. As a solution, a structural change and transformation were expected in the MoNE for planning, coordination, and interaction, and communication between organizations. It was aimed to implement specified solutions through educational administrators expected and desired to be trained.

\section{$2^{\text {nd }}$ Five-Year Development Plan (1968--1972)}

This plan consisted of 11 sections. Education was addressed in the $6^{\text {th }}$ section, from page 158 to 187 . This plan revealed the organization and coordination among the educational institutions within the MoNE as expressed in "all educational institutions should be gathered within the Ministry of National Education" (p. 159), revealed supervision, evaluation, and cooperation with universities as expressed in "with the understanding explained in the principles, the supervision of private schools and provision of a certain standard of education and physical conditions will be observed, and those in higher education will continuously work under the supervision of an interuniversity board under the direction of Ministry of National Education" (p. 176), and revealed inter-institutional cooperation, and contribution and participation of institutions to education as expressed in "the in-service training in industry concerns the Ministry of National Education" (p. 186).

In this development plan, it was aimed to provide coordination, organization, supervision, and evaluation from MoNE, and to communicate and cooperate with relevant institutions in terms of education, especially universities. However, expressing the issues of coordination, organization, and cooperation in the previous plan, and this plan also indicated that the problems could not be solved and continued to exist.

\section{$3^{\text {rd }}$ Five-Year Development Plan (1973--1977)}

This plan consisted of 6 sections. Education was addressed in the $12^{\text {th }}$ part of the $4^{\text {th }}$ section, from page 709 to 780 . The MoNE was criticized for not performing its coordination and organizing functions expected from it in previous plans. Article 1455: "Administrative structures and personnel status of the Ministry of National Education and other educational institutions are far from ensuring the necessary internal planning, program development, and similar procedures for the implementation of the education policies envisaged in the plans and programs“ (p. 715). After the criticisms, organizing the MoNE to target the development in the current plan, making it functional, and grounding on the decisions and implementation to reach the goals in the plan was expressed in article 1565/7 as follows: "It will be ensured that all educational organizations, especially the Ministry of National Education, will be reorganized to effectively implement the educational developments in the envisaged long term and to spread them to a nation-wide level. Decision-making and implementation activities envisaged by the Plan will be developed by grouping the overgrown, complex, and dysfunctional central organization of the Ministry of National Education into functional groups based on the administrative principles". It was seen that the mentioned conditions had not been achieved in the previous plan, and organization and planning processes in the MoNE had been brought to the fore. 


\section{$4^{\text {th }}$ Five-Year Development Plan (1979--1983)}

This plan consisted of 4 sections. Education was addressed in the $5^{\text {th }}$ part of the $2^{\text {nd }}$ section, from page 433 to 459 . Development-oriented reorganization of the education system was described in article 1637.1 with a dominating understanding by taking the environment into account as follows: "It is necessary to reorganize the education system to provide the ability to improve the physical and social environment of the individual and to be a factor bringing society to a further development stage". In this regard, it was seen that it was aimed in MoNE to make arrangements based on the development of educational organizations in article $1637 / 6$ as follows: "All organizations related to education, especially the Ministry of National Education, will be restructured to effectively implement the educational developments and spread them to a nation-wide level".

The request for a change in the structure of the Ministry of National Education was stated in the special specialization commission of education as follows "According to the principles of planning and coordination introduced by the Basic Law of National Education, the decision mechanisms in the central and provincial organizations of the Ministry should be rearranged in a way to focus on vocational technical education" (p.55). The organizing and planning function of MoNE was emphasized in this plan. Special importance was placed on communication with the environment.

\section{$5^{\text {th }}$ Five-Year Development Plan (1985--1989)}

This plan consisted of 5 sections. Education was addressed in the 4th section, from page 140 to 147. As in the 1st FYDP, the plan addressed the training of educational administrators. Article 520 was as follows: "Emphasis will be placed on training highly qualified referral and administrators through in-school and non-formal education" (p. 140). However, there were no principles or goals in the education section to support this idea. In this plan, higher education was included in only one article (article 531, p. 140) in terms of preparation for teaching. This plan considered the training of educational administrators and it was seen that the planning works came to the fore in terms of school administration.

\section{$6^{\text {th }}$ Five-Year Development Plan (1990--1994)}

This plan consisted of 4 sections. Education was addressed in the $4^{\text {th }}$ section, from page 291 to 296. Educational administrators were provided with the duty of determining and resolving problems in the plan and implement it. In this regard, article 813 was as follows: "For each education level, the aim of improving the problem determining and solution-seeking skills of the educational units in the provinces will be taken as a basis" (p. 294). Making arrangements in terms of educational administration was also included in this plan. Article 815 was as follows: "...arrangements to improve educational administration will be made" (p. 294). In addition to this, in this plan, making arrangements for making use of leisure time was also mentioned among the duties of educational administrators. Article 855 was as follows: "Central administrations, municipalities, and village administrations will be guiding in making use of leisure time" (p. 297). Encouraging decision-making for determining and solving problems in terms of educational administration by attaching importance to leisure time can be considered as positive arrangements. Uncertainty about what the measures to 
improve educational administration are can be considered as negative arrangements. In terms of educational administration, this plan draws attention to the planning and organizing practices for the skills of administrators.

\section{$7^{\text {th }}$ Five-Year Development Plan (1996--2000)}

This plan consisted of 4 sections. Education was addressed in the $2^{\text {nd }}$ section, from page 23 to 34 . There is an important approach in the $7^{\text {th }}$ FYDP. This approach was reflected as "education will be the top priority in this plan period" (p. 27). In addition to this, the attempt to make use of culture, physical education and sports, and leisure time services together can be considered as a positive perspective. Although the importance of education was emphasized, the fact that education was expressed in only 11 pages in the plan consisting of 219 pages suggested that there was a contradiction regarding this positive approach. As a solution to all these problems, it was requested to revise 1739 numbered National Education Basic Law, 222 numbered Primary Education and Training Law, and 3797 numbered Law on Organization and Duties of MoNE within the framework of legal and institutional arrangements. The arrangements were expected to be planned within the framework of cooperation. This situation was revealed as follows:

Arrangements will be made in 3797 numbered Law on Organization and Duties of MoNE to realize a structuring based on service in national education, to turn the central organization into a high-level decision-making body that will deal with strategic planning, curriculum, research and development, supervision, and coordination tasks at the macro level, to reduce bureaucracy, to transfer the authority and responsibility to the provincial units of the Ministry and local administrators, and to ensure the active participation of Ministry provincial organizations, local administrations, and families in the serving process of education. $\left(7^{\text {th }}\right.$ FYDP, p. 33)

Considering the $7^{\text {th }}$ FYDP, expressing education as a priority can be considered as an important paradigm shift; however, its place in the whole plan and the absence of expressions supporting this in the following articles constitute doubts in terms of putting the specified changes into action. This plan adopts a planning approach in which change and development will be implemented based on the legislation directing education.

\section{$8^{\text {th }}$ Five-Year Development Plan (2001--2005)}

This plan consisted of 10 sections. Education was addressed in the $8^{\text {th }}$ section, from page 80 to 85 . In this plan, the articles between 99 and 111 were devoted to evaluations and developments in the field of education. It was attempted to bring the things that were done to the forefront rather than those that could not be done. In addition to these articles, there were also other articles including explanations about education. Article 186 drew attention to the connection among contribution to the economy, values, and high-level mental skills in terms of educational goals. "The goal of the education system is to educate people of the information age, who adhere to Atatürk's principles and reforms, adopt democratic values, internalize national culture, interpret different cultures, can think, perceive, and solve problems, and have creative thinking” (p. 25). To achieve this goal, different administration practices were included in article 683 as "A model based on performance measurement, which also takes into account total quality management, will be developed for evaluating the success of educational institutions and imbalances between regions will be eliminated" and the 
contribution of the environment to this administration activities was explained in article 685 as "local administrations, voluntary organizations, and the private sector will contribute to the dissemination of education as well as the central administration" (p. 83). In addition to this, it was aimed to change the Law on Organization and Duties of MoNE and change the structure of higher education (articles 700 and 705, p. 85).

Among the aims and principles determined by the secondary education specialization commission, "in-service training of human resources in the education system should be made effective by reflecting them on their personal rights" (p. 82) and "necessary amendments should be made in the relevant legislation to facilitate the effective and efficient use of human and non-human resources in education" (p. 83) principles were included. The goal for these principles were set as follows: "To provide inclusive education at the secondary education level, 50 institutions should be equipped with the necessary structure, functioning and equipment for the successful implementation of this education and should supported by sufficient personnel" (p. 83). The evaluations included in the report emphasized the review of educational administration in terms of personnel, stakeholders, and organization.

Considering the goals, it was seen that the $8^{\text {th }}$ FYDP was brought up to the agenda to include different administration practices with the contribution of the environment. As a solution in education, it was suggested to make changes in the structure of MoNE based on the legislation and it was planned to change the structure of CoHE. Communication and cooperation between MoNE and CoHE were also considered to be among the plans.

\section{$9^{\text {th }}$ Development Plan (2007--2013)}

It was seen that two changes were implemented with this plan. In this plan, the 'five-year' expression and the contents section were removed. Instead, 'development plan' expression and explanations under items were preferred. The subject of education was included in articles from 570 to 577 and articles from 581 to 602 (pp. 84-85; 8587). The effect of the European Union membership process can be observed in 9th DP (article 9, p. 3; article 54, p. 12). Including education in a vision document can be considered as an important approach (p. 4). Problems related to education were mentioned (article 238-260, pp. 40-43). Another point drawing attention in this plan was that the concept of "sustainable" was included for the first time in various parts of the plan, including education (such as article 561, p. 83; article 581, p. 85; article 616, p. 88). The duty of cooperating with the environment to expand education in terms of educational administration was addressed in article 587 as "apart from the central administration, the contribution of local administrations, voluntary organizations, and private sector will be increased in disseminating education" (p. 86), the targeted structural changes were addressed in article 600 as "a service-based structure will be established in the central organization of MoNE, institutional capacity will be improved, and authority and responsibility will be delegated to the provincial organizations and educational institutions" (p. 87), the arrangements regarding the CoHE were addressed in article 601 as "the CoHE will be restructured to be responsible for setting standards, coordination, and planning" (p. 87), and arrangements regarding authority and performance in educational institutions were addressed in article 602 as "the authorities 
and institutional capacities of educational institutions will be increased and a model based on performance evaluation will be developed" (p. 87).

It was seen that the views on regulating the Ministry of Education were discussed in the "Education: Preschool, Primary and Secondary Education special expertise commission". A proposal was made in the commission as follows: "In the new regulations, the role of the Ministry of National Education to be responsible for all types and levels of education other than higher education should be preserved. The central organization of the Ministry of National Education should have an institutional structure that determines more policies, conducts research and planning, guides, pioneers and supervises with pilot applications" (p.74). In addition to this, another proposal was as follows: "The structure and administration of educational institutions should be reorganized with a participatory understanding" ( $p$. 75). It is believed that these recommendations are based on the transformation of the Ministry of Education within itself. It can be said that a participatory understanding is adopted for this.

In this plan, it was seen that emphasis was placed on inter-institutional cooperation, planning, organization, coordination, evaluation process, and balance of authority and responsibility. For establishing the specified balance, structural changes and a transformation were planned in MoNE as in previous plans.

\section{0 $^{\text {th }}$ Development Plan (2014--2018)}

As in the previous plan, the explanations were made as articles. Education was included in articles from 137 to 165 (pp. 31-35). In this plan, the supervision and evaluation regarding the educational administration were addressed in article 151 as "multiple evaluation and supervision mechanism will be developed at the national level" (p. 34), the authorities and responsibilities of school administration were addressed in article 154 as "authorities and responsibilities of school administrations in budgeting processes will be increased" (p. 34), and the structure of the CoHE was addressed in article 161 as "higher education system will be transformed into a qualityoriented competitive structure within the framework of the principles of autonomy, performance orientation, specialization, and diversity based on accountability" (p. 34).

In the special expertise commission aimed at increasing the quality of the education system, the followings were proposed: "increasing the quality of teachers and administrators, ensuring equal opportunity in access; reducing the differences in human and physical infrastructure between provinces and schools, improving decision processes, activating the monitoring and evaluation activities, increasing accountability, setting meaningful learning goals, continuously evaluating and improving programs, following policies to realize social justice in education, decentralizing educational administration and delegating authority, and diversifying and increasing public and private resources allocated for education" (p. 43). The above-mentioned issues showed that the understanding that taking into consideration the development-oriented training and management processes within the profession would contribute to the success in school was dominant in the plan.

As in previous plans, it is considered that this plan is important in terms of bringing the administrative processes to the agenda, emphasizing the school administration, and the change in the structure of the CoHE, including the concept of 
sustainability, and providing the MoNE with the coordination duty regarding the educational cooperation of various fields.

\section{$11^{\text {th }}$ Development Plan (2019--2023)}

It can be said that this development plan is the continuation of the previous one. Education was included in articles from 547 to 563 (pp. 126-131). Initially, as in each plan, explanations were made with articles for evaluating the previous plan. Considering education, articles 149, 150, and 153 can be exemplified (pp. 24-25). These articles indicated developments in education (one of the two priority areas according to the plan), improvement in infrastructure, and increased services. It was seen that 4 articles regarding educational administration came to the fore. First, article 553.3 addressed the professionalization of school administration, which could be also expressed as a bleeding wound in educational administration, and the training of administrators. The related article was as follows: "School administration will be transformed into a professional profession and an administrative accreditation structure will be created" (p. 127). Second, article 553.7 encouraged school administration. The related article was as follows: "Considering the student acquisition, incentive mechanisms will be created for teachers and school administrators at different rates depending on the type and location of the educational institutions they work at" (p. 128). Third, article 553.9 addressed the in-service training needs of school administrators. The related article was as follows: "The content of in-service training will be renewed in line with the current needs of teachers and school administrators." Fourth, article 554.2 addressed changing the understanding of administration.

In addition to this, it was seen that the arrangements regarding the duties of CoHE included project-centered arrangements. The related article, article 440.2, was revealed as follows: " .... a coordination and support unit will be established within CoHE to strengthen the harmony between the plan objectives and projects..." (p. 100). It can be said that this plan aims at continuing and developing the practices of the previous plan. It can be considered as an important development to include the concept of governance concerning the educational administration as well as providing more space for the concept of sustainability.

It was seen that the special expertise commission for improving the quality in the education system had policy proposals regarding school administration. One of the proposals in this regard was as follows: "The quality of school administration should be improved and its autonomy should be ensured" (p. 62). The suggestion was meaningful as it indicated the place of the school administration in education. It was believed that this proposal would contribute to the solution as "... the adoption and implementation of the measures to be taken by all stakeholders, especially the Ministry of National Education, will help to eliminate the quality problem in education" (p. 62). It was determined that the understanding of taking the opinions of all the environment that could contribute to the school administration in the measures to be taken was adopted in this evaluation.

This plan includes the professionalization of school administration in terms of educational administration, the training of educational administrators, and the practices for promoting school administration. This plan also includes arrangements regarding various administration practices, such as reducing bureaucracy, ensuring information 
security. It is requested for the CoHE to adopt a project-oriented structure. It is thought that goals for planning, coordination, and cooperation, and interaction with the environment are included in this plan.

\section{Discussion and Conclusion}

The transition to the planned period in Turkey in 1963 reveals the need for planning in the field of education as in all other fields. It was seen that there were various expectations about education in the plans (Beach \& Lindahl, 2015; Kaya, 2015, p. 374; Küçükali, 2011, p. 63). However, when the plans were evaluated in terms of educational administration, it was seen that the following issues come to the fore: The understanding of planning and coordinating educational administration centered on the Ministry of National Education was dominant. For this, special importance was placed on obtaining the opinions of the ones to be affected by the plans of the MoNE, and cooperating with various institutions and organizations. Organizational arrangements legal regulations - were expected for the planned changes. Considering the organizational arrangements in planning, Kondakçı and Zayim (2013) recommended that the targets should be realistic and should be needs-oriented for success. In addition to this, they also recommended that the relevant people should have a good command of the job and follow the work as well as coordinating and organizing the resources to be used in practice properly. Yıldız and Karakütük (2017) emphasized the importance of having experienced and qualified employees. In studies conducted, it was emphasized that planning involving education and the related environment is indispensable to ensure coordination within the organization. (Bennell, 2015; Boyac1, 2009; Chua, 2006; Özdoğan, 2012; Potts, Vella, Dale, \& Sipe, 2016; Uvalić-Trumbić \& Daniel, 2016; Yinfu, 2017). Teksöz (2014) emphasized that it was the right approach to cooperate with MoNE, CoHE, and other organizations in the context of the environment in sustainable development. Oghenekohwo and Torunarigha (2018) emphasized that not paying enough attention to education in the plans may prevent the implementation of values such as equality and social justice and thus limit development. It can be said that the results of the analyzes are in parallel with the findings in the relevant literature regarding the necessity of planning, how it should be done, and its benefits. However, it is thought that the analysis results for the planning and coordination function of the Ministry of National Education in the present study are not in parallel with the relevant literature as the research findings regarding all development plans in Turkey are insufficient.

One of the issues determined in the development plans was the expectations from the educational administrators. Educational administrators were expected to prepare plans in the organizations. For proper planning, the competencies and skills of educational administrators that could bring the plan to life were valued. In this regard, the educational administrators were expected to include the education-training requirements and innovations required by the age in planning (Douse \& Uys, 2018), have professional knowledge and skills related to the plan (Nir, 2016), conduct a supervision and evaluation for the plan (Speck, 1999, p. 69), and receive adequate training (Arslan \& Küçüker, 2016). For this, an educational administrator should know the different dimensions of planning and be able to establish a balance between the resources and goals (Gökalp, 2003; Gümüş \& Şişman, p. 148; Hess et al., 2014; 
Küçüker, 2008; MoNE, 1973; Özdemir, 1997). It can be concluded that the results of the analyzes and the studies are in parallel with each other in this regard.

Another point that drew attention in the plans was the attempt to reflect the approach stated as administration processes in the literature to the plans. It was seen that each plan included a different number of process elements. It was expected from the administrative processes to bring success in reaching the goals, especially in terms of planning. In the processes, direct or indirect effects of planning and organization on all plans could be seen. These effects were first felt in the evaluation of past plans. Başaran (1993, p. 43) and Aydin (2000, p. 121) stated that the administrative processes would contribute to the solution of administrational problems and administrators' coping with the problems. However, a process based on a certain systematicity, continuity, and determination could not be reflected in the plans (Ersöz, 2014; Tuzcu, 2005; Y1ld1z \& Karakütük, 2017). Failure to apply administrative processes to the plans can cause problems in achieving goals (Argün, 2003; Aşım, 2019; Bulut, 2002; Gül, 1992; Korkmaz, 1995; Taş, 2007; Yetkin-Ay, 2010). However, an understanding of governance based on cooperation between the administration and the administered can contribute to overcoming the problems regarding sustainable development (Kayıkçı, 2018; DSB, 2018). All these evaluations are significant in terms of showing why similar points are repeated in the plans outlined in this specific study. This inference suggests that the results of the analysis are in parallel with the relevant literature.

\section{Implications}

It can be said that the above-mentioned studies are in parallel with this study in terms of explaining how necessary the training planning is and the difficulties experienced in this subject. However, it is difficult to say that the results of this study are in parallel with the previous studies in terms of educational administration. It is thought that there are two reasons for this. First, this study is based on the examination of all plans. Except for Karakütük (2019), no other study included all development plans in Turkey. Second, it is thought that there is not enough research on the relationship between planning and educational administration. In this study, there are various implications for educational administration, especially for administrative processes and the impact of the environment (Table 1).

The following suggestions can be made based on the fact that development plans include and direct educational administration as well as all areas. It can be recommended for the researchers to examine available plans by considering different aspects of education. The relationship between planning and educational administration can be investigated by considering various dimensions of educational administration. Research can be carried out by using different methods for the specified issues. All development plans can be included in the studies to be carried out. It can be recommended for the practitioners to make decisions in line with the plan targets by considering the importance of planning. Administrative processes can be reflected in the plans better and clearly. The opinions of educational administration experts, who are expected to be one of the environmental elements in the planning process, can be reflected more in the plans to be made. 


\section{References}

Adem, M. (1979). Planlı bir eğitim düzeni kurulmalıdır. Eğitim ve Bilim, 4(21), 3-16.

Akar, G. (2010). Insan kaynaklarında eğitim planlaması ve çalışanların eğitim uygulamalarına ilişkin algıları (Yayımlanmamış Yüksek Lisans Tezi). Gazi Üniversitesi, Ankara.

Akça, Y., Şahan, G., \& Tural, A. (2017). Türkiye'nin kalkınma planlarında eğitim politikalarının değerlendirilmesi. International Journal of Cultural and Social Studies (IntJCSS), 3, 394-403.

Alexander, E. R. (2001). What do planners need to know? Journal of Planning Education and Research, 20, 376-380.

Alterman, R. (2017). From a minor to a major profession: can planning and planning theory meet the challenges of globalisation? Transactions of the Association of European Schools of Planning, 1, 17. http://dx.doi.org/10.24306/TrAESOP.2017.01.001

Altundemir, M. E. (2012). Kalkınma planlarından eğitime bakış: kamusal mallar teorisi perspektifinden. The Journal of Knowledge Economy \& Knowledge Management, Bilgi Ekonomisi ve Yönetimi Dergisi, 7(1), 94-105.

Argün, H. (2003). Planlı kalkınma döneminde (1963-2002) mesleki ve teknik eğitim (gelişmeler, uygulamalar, sorunlar) (Yayımlanmamış Yüksek Lisans Tezi). Gazi Üniversitesi, Ankara.

Arslan, G., \& Küçüker, E. (2016). Okul müdürlerinin planlama etkinlikleri ve stratejik planlamada karşılaşılan sorunlar. Kastamonu Eğitim Dergisi, 24(2), 839-856.

Aşım, M. (2019). Kalkınma planlarında halk eğitiminin tarihsel gelişimi (Yayımlanmamış yüksek lisans tezi). Marmara Üniversitesi, İstanbul.

Aydın, M. (2000). Ĕ̆itim yönetimi (6. bask1). Ankara: Hatipoğlu.

Balyer, A. (2019). Eğitim yönetiminde yeni yaklaşımlar (1. bask1). Ankara: An1.

Başaran, İ. (1993). Eğitim yönetimi (1. baskı). Ankara: Gül Yayınevi.

Bayram, A. (2019). The viewpoints of educational managers on educational planning in Turkey. European Journal of Education Studies, 6(7), 452-462. http://dx.doi.org/10.5281/zenodo.3528377

Beach, R. H., \& Lindahl, R. A. (2015). A discussion of strategic planning as understood through the theory of planning and its relevance to education. Educational Planning, 22(2), 5-16.

Bennell, S. J. (2015). Education for sustainable development and global citizenship: Leadership, collaboration, and networking in primary schools. International Journal of Development Education and Global Learning, 7(1), 5-32.

Boyac1, A. (2009). İlköğretim okulu öğretmenlerinin eğitim planlaması süreçlerine yönelik kullandıkları metaforlar. Selçuk Üniversitesi Sosyal Bilimler Enstitüsü Dergisi, 21, 111-123.

Bulut, E. (2002). Yedinci beş yıllık kalkınma planında eğitim hedefleri ve gerçekleşme düzeyi (Yayımlanmamış Yüksek Lisans Tezi). İnönü Üniversitesi, Malatya.

Bursalığlu, Z. (2000). Okul yönetiminde yeni yapı ve davranış (11. bask1). Ankara: PegemA. 
Christensen, L. B., Johnson, R. B., \& Turner, L. A. (2015). Araştırma yaklaşımları ve veri toplama yöntemleri. A. Boyacı, \& K. Bozkuş (Çev.), A. Aypay (Çev. Ed.) içinde, Araştırma yöntemleri desen ve analiz (ss. 30-71). Ankara: Anı.

Chua, C. S. K. (2006). Singaporean educational planning: moving from the macro to the micro. Current Issues in Language Planning, 7(2-3), 214-228. http://dx.doi.org/10.2167/cilp095.0

Crowson, R. L. (1992). School community relations, under reform $\left(1^{\text {st }}\right.$ ed.). Berkeley: McCuthcan Publishing Corporation.

Çakmak, Ö. (2008). Eğitimin ekonomiye ve kalkınmaya etkisi. D. Ü. Ziya Gökalp Eğitim Fakültesi Dergisi, 11, 33-41.

Davidovitch-Marton, R. (2007). The education system as a platform for involving the public in planning processes. Children, Youth and Environments, 17(3), 85-98.

Douse, M., \& Uys, P. (2018). Educational planning in the age of digitisation. Educational Planning, 25(2), 7-23.

Ekiz, C., \& Somel, A. (2007). Türkiye'de planlama ve planlama anlayışının değişimi. Mülkiye Dergisi, 31(256), 97-136.

Ergen, H. (2013). Türkiye'de eğitimde planlama yaklaşımları ve kullanılan eğitim göstergeleri. Mersin Üniversitesi Eğitim Fakültesi Dergisi, 9(2), 151-167.

Ersöz, G. (2014). Geçmişten ders almak: sürdürülebilir kalkınma için eğitim. Boğaziçi Üniversitesi Eğitim Dergisi, 31(2), 73-97.

Fullan, M. G. (1992). Successful school improvement (1 ${ }^{\text {st }}$ ed.). USA: Open University Press.

Gökalp, M. (2003). Türk eğitim sisteminin kalkınma planları doğrultusunda ihtiyaç duyduğu insan gücü niteliklerinin belirlenmesi ve buna uygun ögretmen yetiştirilmesi (Yayımlanmamış doktora tezi). Atatürk Üniversitesi, Erzurum.

Gül, H. (1992). Kalkınma planlarında eğitime ilişkin sayısal hedefler ve gerçekleşme düzeyi (Yayımlanmamış yüksek lisans tezi). İnönü Üniversitesi, Malatya.

Gümüş, E., \& Şişman, M. (2012). Eğitim ekonomisi ve planlaması (1. baskı). Ankara: PegemA.

Günkör, C. (2017). Eğitim ve kalkınma ilişkisinin incelenmesi. Uluslararası Sosyal Bilimler Eğitimi Dergisi Journal of International Social Sciences Education, 3(1), 14-32.

Hess, M., Johnson, J., \& Reynolds, S. (2014). A developmental model for educational planning: democratic rationalities and dispositions. NCPEA International Journal of Educational Leadership Preparation, 9(1) - March, 2014. Retrieved from https://files.eric.ed.gov/fulltext/EJ1024108.pdf

Karakütük, K. (2019). Eğitim planlaması (3. bask1). Ankara: PegemA.

Kaya, Y. K. (2015). Insan yetiştirme düzenimiz (6. bask1). Ankara: PegemA.

Kayıkçı, S. (2018). Yönetişimin kamu kurumlarında uygulanabilirliği: yükseköğretim kurulu başkanlığı örneği. Ombudsman Akademik, 1, 163-181.

Koçel, T. (2001). İşletme yöneticiliği (8. bas1). İstanbul: Beta.

Kondakçı, Y., \& Zayim, M. (2013). Yönetim süreçleri. S. Özdemir (Ed.) içinde, Eğitim yönetiminde kuram ve uygulama (ss. 9-62). Ankara: PegemA. 
Korkmaz, A. (1995). Kalkınma planlarında öngörülen eğitim hedeflerinin gerçekleşme düzeyi (Yayımlanmamış doktora tezi). Gazi Üniversitesi, Ankara.

Küçükali, R. (2011). Yönetim felsefesi (1. basım). Ankara: Nobel.

Küçüker, E. (2008). Kalkınma planları kapsamında yapılan ĕgitim planlarının analizi (1963-2005) (Yayımlanmamış doktora tezi). Ankara Üniversitesi, Ankara.

Merriam, S. B. (2015a). Nitel araştırma nedir? S. Turan (Çev.), S. Turan (Çev. Ed.) içinde, Nitel araştırma desen ve uygulama için bir rehber (ss. 3-20). Ankara: Nobel.

Merriam, S. B. (2015b). Nitel araştırmalarda geçerlik, güvenirlik, etik. E. Dinç (Çev.), S. Turan (Çev. Ed.) içinde, Nitel araştırma desen ve uygulama için bir rehber (ss. 199-228). Ankara: Nobel.

Milli Eğitim Bakanlığı (MEB) (1973). Millî ĕgitim temel kanunu, http://www.meb.gov.tr adresinden alınmıştır.

Neuman, W. L. (2006). Toplumsal araştırma yöntemleri (4. basım). S. Özge (Çev.). İstanbul: Yayınodasi.

Nir, A. E. (2016). Educational planning: the ethics of compromise. Educational Planning, 23(1), 5-17.

Oghenekohwo, J. E., \& Torunarigha, Y. D. (2018). Education and development: dynamics of access, equity, and social justice in Nigeria. International Journal of Education \& Literacy Studies, 6(2), 10-14.

Özdemir, B. (1997). Planl kalkınma döneminde (1963-1995) ilköğretim politikalarındaki gelişmeler (Yayımlanmamış Yüksek Lisans Tezi). Abant İzzet Baysal Üniversitesi, Bolu.

Özdoğan, E. (2012). Yükseköğretim yöneticilerinin bireysel planlama davranışlarının örgütsel planlama davranışlarına etkisi konusundaki görüşleri (Yayımlanmamış Yüksek Lisans Tezi). Ankara Üniversitesi, Ankara.

Patton, M. Q. (2014a). Nitel araştırmanın doğası. M. Bütün \& S. B. Demir, (Çev.), M. Bütün \& S. B. Demir (Çev. Ed.) içinde, Nitel araştırma ve değerlendirme yöntemleri (ss. 3-36). Ankara: PegemA.

Patton, M. Q. (2014b). Nitel analiz ve yorumlama. A. Çekiç \& A. Bakla, (Çev.), M. Bütün \& S. B. Demir (Çev. Ed.) içinde, Nitel araştırma ve değerlendirme yöntemleri (ss. 431-540). Ankara: PegemA.

Persaud, A. (2017). Integrated planning for education and development. European Journal of Education, 52(4), 448-459.

Potts, R., Vella, K., Dale, A., \& Sipe, N. (2016). Exploring the usefulness of structuralfunctional approaches to analyse governance of planning systems. Planning Theory, 15(2), 162-189.

Sezgin-Nartgün, Ş. (2000). Stratejik planlama ve eğitim. C. Elma, K. Demir (Ed.) içinde, Yönetimde çağdaş yaklaşımlar (ss. 277-300). Ankara: Anı Yayıncılık

Soyak, A. (2003). Türkiye'de iktisadi planlama: DPT'ye ihtiyaç var mı? Doğuş Üniversitesi Dergisi, 4(2), 167-182.

Speck, M. (1999). Building a learning community ( $1^{\text {st }}$ ed.). New Jersey: Prentice-Hall, Inc. 
Taş, U. (2007). Türkiye'de kalkınma planları ışığında eğitimin kalkınmadaki rolü (Yayımlanmamış Yüksek Lisans Tezi). Eskişehir Osmangazi Üniversitesi, Eskişehir.

Teksöz, G. (2014). Geçmişten ders almak: Sürdürülebilir kalkınma için eğitim. Boğaziçi Üniversitesi Eğitim Dergisi, 31(2), 73-97.

Tian, L. (2016). Behind the growth: planning education in china during rapid urbanization. Journal of Planning Education and Research, 36(4), 465-475. http://dx.doi.org/10.1177/0739456X15618014

Tuzcu, G. (2005). Avrupa birliği'ne giriş sürecinde Türkiye’de eğitim planlaması (Yayımlanmamış doktora tezi). Ankara Üniversitesi, Ankara.

Türkiye Cumhuriyeti Cumhurbaşkanlığı Strateji ve Bütçe Başkanlığı (SBB) [The Presidency of the Republic of Turkey, Directorate of Strategy and Budget (DSB)]. (2018). Kalkınma planlarl [Development plans](1-11), www. sbb.gov.tr adresinden alınmıştır.

Türkiye Cumhuriyeti Cumhurbaşkanlığı Strateji ve Bütçe Başkanlığı (SBB) [The Presidency of the Republic of Turkey, Directorate of Strategy and Budget (DSB)]. (2018). Özel ihtisas komisyonu raporları [Special expertise commission reports] (4., 8., 9., 10., 11. Kalkınma planlart [Development plans]), www. sbb.gov.tr adresinden alınmıştır.

Uvalić-Trumbić, S., \& Daniel, S. J. (2016). Sustainable development begins with education. Journal of Learning for Development, 3(3), 3-8.

Yetkin-Ay, A. (2010). Sekiz yıllık kesintisiz temel eğitime geçişten günümüze kalkınma planlarının ilköğretimde okullaşma oranı ve sınıf mevcudu açısından irdelenmesi (Yayımlanmamış yüksek lisans tezi). Akdeniz Üniversitesi, Antalya.

Yıldız, S., \& Karakütük, K. (2017). Planlı dönemde eğitim planlaması çalışmalarının değerlendirilmesi. Mersin Üniversitesi Eğitim Fakültesi Dergisi, 13(2), 703-725. doi: http://dx.doi.org/10.17860/mersinefd.317978.

Yıldırım, A., \& Şimşek, H. (2011). Sosyal bilimlerde nitel araştırma yöntemleri (8. bask1). Ankara: Seçkin.

Yinfu, Y. (2017). Concepts and policy innovations in the national education plan. Chinese Education \& Society, 50, 142-161. 